\title{
Increasing Science Literacy through Collaboration between Teachers and School Library Media Specialists
}

\author{
Barbara Schultz-Jones \\ Assistant Professor \\ University of North Texas \\ USA \\ Cynthia Ledbetter \\ Professor \\ University of Texas at Dallas \\ USA \\ Richard C. Jones \\ Associate Professor \\ Texas Womans' University \\ USA
}

This paper presents current research, and complementary perspectives on how and why interdisciplinary collaboration efforts contribute to positive outcomes for student science achievement. Undergraduate students, practising science teachers, and school library media specialists are included in this discussion.

interdisciplinary collaboration; science literacy; school libraries

The development of student science literacy skills is the focus of educators in the United States, nationwide (Martin, Mullis, Gonzalez \& Chrostowski, 2004; National Science Foundation, 2006; Organization for Economic Cooperation and Development [OECD], 2006, 2007). With this national emphasis, the opportunity exists to strengthen the collaboration efforts between science teachers and school library media specialists to impact student science achievement. Along with a positive, constructivist learning environment, the areas that support improvement of literacy are information, media, and communications and technology (ICT) literacy. School library media specialists offer expertise in these areas.

Standards for both professions recognize the value of inquiry-based learning and encourage collaborative learning environments within the school community. Despite these commonalities, collaboration occurs inconsistently in practice and knowledge of each other's professional roles may be minimal.

This paper presents current research, and complementary perspectives on how and why interdisciplinary collaboration efforts contribute to positive outcomes for student science achievement. Undergraduate students, practising science teachers, and school library media specialists are included in this examination. 


\section{Science Literacy: The Players}

\section{Undergraduate students}

Undergraduate students have different usage patterns of information resources than their teachers, and a different appreciation of the value of library resources. Two surveys by Jones (2008) of incoming science undergraduates demonstrate the gaps in their research and library literacy.

The first survey was inspired by a collegial discussion with a faculty member from the biology department, at the beginning of the 2008 fall semester. The discussion centred on what good books were discovered and read over the summer. When one of the biology teaching assistants came by, she was casually asked what she had read over the summer. "Nothing" was her reply. With further probing, her answers were uniformly the same. She simply did not enjoy reading. As a science major she obviously read a lot of volumes - but evidently nothing outside of required science texts and certainly not for pleasure. The collegial discussion then extended to whether this was close to the norm among undergraduate students, and the implications and value of these data. Further investigation followed.

A survey of an undergraduate science class composed of biology and chemistry majors $(\mathrm{N}=26)$ was conducted in that fall 2008 semester. The question for the students was, "who reads and what do they read?" The statistics revealed:

- $80 \%$ do not read for pleasure; only school-required reading

- $8 \%$ read popular authors

- $\quad 8 \%$ read electronic books

- $\quad 8 \%$ claim to read a newspaper (primarily the weekend edition, and then only the “people section” or TV-Movie schedule, or Sudoku puzzle.)

Although a small sample, the proportions were consistent with other surveyed undergraduate science classes for non-science majors $(\mathrm{N}=183)$.

One question that was inspired from these results relates to encouraging reading across disciplines. What deflects them from the written word? Further probing and interviews revealed the following answers from these undergraduate students:

- Time management - "I barely have time to do my required reading".

- Burnout - "I have so much to do that when I do have free time I just want to collapse”.

- $\quad$ Lack of interest - "Why should I read something that has nothing to do with my major?”

- Digital ease - "Why should I read something when I can look it up (via Internet) on my phone?”

- Short attention spans - most of their responses to problem solving reflected their "bumper sticker" and "sound bite" culture: problems can be answered in seven words or seven seconds.

- Mercurial digital culture - a subset of short attention spans - they expect short and quick solutions, they are bored and lost with long and convoluted plot lines.

- Obsolescence challenge - paper books and newspapers are artefacts of their parents and grandparents - electronics are "cool”. 
One disturbing comment heard more than once in this exploration of attitudes towards reading was the statement: "I am a graduating senior and I have never been to the library." It was difficult to know if this was a courageous statement of knowing more than what is available in the library or a statement suggesting libraries are redundant and/or obsolete (Google is better than...)? Or are libraries somehow physically or psychologically scary or offensive (not user friendly)? Library anxiety was first described in 1986 by Constance Mellon, at the University of North Carolina. She discovered that in a sample group of first year students, $75 \%$ to $85 \%$ of the students described their initial response to library research in terms of fear. This is a reaction/fear not usually anticipated by professors, and possibly a question of how students perceived their school library learning environment.

These and other ruminations lead to another fall 2008 survey of undergraduate science classes for non-science majors ( $\mathrm{N}=183)$, that asked the question: "Do you use the library on a regular basis (meaning at least once per week)? The results were:

- $100 \%$ Freshmen (first year undergraduate)

- $\quad 40 \%$ Sophomores (second year undergraduate)

- $15 \%$ Juniors (third year undergraduate)

- $5 \%$ Seniors (fourth year undergraduate)

Ethnic group distribution: (Caucasian 50\%, Asian 2\%, Hispanic 32\%, Black 13\%, other 3\%)

Since the freshmen statistic was startling, further probing revealed that all freshmen are now required to take a "University Survival Course" which has a large library component. This course was introduced in 2007 and the impact may eventually counter the disturbing trend of the subsequent years where the longer you stay in University, the less you utilize the library. And, a more telling question may be "Do you use the library resources on a regular basis (at least once per week), recognizing the influence of networked digital resources, available in the comfort of dormitories, homes, or other locations on campus.

However, the introduction of a mandatory course with library instruction suggests that information literacy skills are being remediated at the college level. A quick review of local universities revealed that introductory courses on research instruction are commonplace for many science undergraduate programs. The instructors of these courses emphasized that entry level undergraduates are leaving high school without the requisite research skills to be successful in their first year of college. This gap is an opportunity for school library programs to identify a value-added service and provide substantive evidence of student achievement when school library practices are applied. Increasing science literacy and the ability to conduct comprehensive research is a shared goal for science teachers and school library media specialists.

\section{Science teachers}

Science teachers in grades 6 through 8 also have varying perceptions of the usefulness of school library resources for themselves, and for their students. In this study, twenty-four participants from a graduate level science education research class were asked to complete a questionnaire designed to determine what science teachers know about librarians and their responsibilities. The Teacher-Librarian Collaboration Survey (TLCS) was based on the Information Literacy Competency Standards for Higher Education (ALA, 2000) and contained four open-ended, free response questions to determine teachers' expectations of the school librarian and their level of collaboration with the librarian. 
The results of the mixed methods study of these middle-school teachers by SchultzJones and Ledbetter (2009) indicated that the teachers underestimate the usefulness of a school librarian's knowledge and professional expertise, particularly in providing research skill instruction to the teachers and the students. But, they demonstrate a willingness to collaborate with school librarians if they are able to develop a method of initiating the interactions. The high response indicating that they believe they need to learn methods for engaging in collaborations suggests inexperience and a lack of confidence in enacting collaboration. This lack of collaborative skill coupled with a lack of knowledge of the value that school librarians add, contribute to a low level of engagement between the disciplines in the school community.

One of the main reasons these public school science teachers are ignorant of the value added by school librarians is the lack of a collaborative focus and attention to the school librarian as a resource, during pre-service education. These results support the previous findings of Hartzell (1997) and Wolcott, et al. (1999) who highlighted the lack of vision that teachers hold of school librarian potential in part due to a lack of exposure during teacher training programs. As Small (2002) states: "Collaboration cannot be fully realized without creating a collaborative culture in which all partners see the importance and understand the benefits of collaboration to themselves, each other and their students” (đPre-service Education). The persistence of continuing evidence that pre-service teachers are not oriented to the value of school librarian potential is disappointing. Efforts to engage pre-service educators remain a priority for library science educators, yet success stories from these ventures remain unpublished and shared.

\section{School library media specialists}

School library media specialists experience resistance to collaborative efforts and may themselves be uncomfortable initiating interaction with teachers. A large body of research demonstrates that collaboration is a primary focus for school librarians. Results of a recent study by Schultz-Jones (2009) also demonstrate the complexity and variety of school librarian collaboration networks in the school learning environment. A 2008 pilot study mapped the social networks of five school library media specialists within three school learning communities. While each school librarian in the study maintained that collaboration was a key priority, the range and level of collaboration varied, regardless of the experience level of the school library media specialist. Successful collaboration requires tremendous time and energy, targeting potential collaborators and developing a corresponding strategy to connect across a school learning community.

An interesting theme from this study was the consistent appearance of strategic groups. The networks demonstrated clusters of contacts for levels of collaboration and frequency of collaboration. These clusters were not equivalent for levels and frequency. Instead, they had a high degree of contiguity, with each cluster containing contacts from more than one subject area. This graphically demonstrated the ability of school library media specialists to move across disciplines and contribute expertise, regardless of subject specialty. The contribution to science literacy has the same potential as contributing to literacy in any subject area. The overarching goal of contributing to student achievement retains a central focus.

These small and seemingly disconnected studies provide clues for extending research opportunities in three key areas for school libraries. First, assessment of the learning 
environment created and nurtured in the school library. How welcoming and engaging is the learning space? A collaborative environment for working with teachers extends to students, and methods to assess this operational climate should be examined and assessed. Additional research in this area will be enlightening.

Second, assess the development and promotion of research skills as a value added service that contributes to $21^{\text {st }}$ century responsible digital citizens and lifelong learners, and students ready for the challenge of continuing education. The AASL Standards for the $21^{\text {st }}$ Century Learner (AASL, 2007) provides an explicit framework to guide a strategy of learning and literacy outcomes. These standards have the potential to frame the scope of school library practice and provide evidence of the impact of school libraries.

Third, develop and share collaborative training and research methods to leverage the expertise of all disciplines in the school learning community. Todd (2008) highlights this need in his discussion of the key challenges of evidence-based practice when he states: "How do we provide professional training in EBP? For starters, by making the training developed in the Delaware and Ohio studies more widely available” (p. 43). As students need training in research skills, so teachers and school librarians need exposure to training opportunities on how to collaborate, deliver information literacy skills and provide the evidence of student achievement in response to these efforts.

The results of these studies suggest that initiating and sustaining an orientation to research skills is a k-12 endeavour shared by teachers and school librarians, and required for undergraduate proficiency in college. Collaboration is needed as are the methods to develop a long term relationship that uses science education resources and develops science and information literacy skills for teachers and students. Increasing students' success in science requires the development of habitual enquiry and research across the curriculum, drawing on the collective strengths of collaborating members of the school learning community.

\section{References}

American Association of School Librarians. 2007. AASL standards for the $21^{\text {st }}$ century learner. Retrieved May 15, 2009 from http://www.ala.org/ala/mgrps/divs/aasl/guidelinesandstandards/learningstandards/standards.cfm American Library Association. (2000). Information literacy competency standards for higher education. Chicago, IL: The Association of College and Research Libraries.

Hartzell, G. N. (1997, November). The invisible school librarian: Why other educators are blind to your value. School Library Journal, 43(11), 24-29.

Jones, Richard. (2008). Unpublished Data. Texas Woman’s University, Denton, Texas.

Martin, M.O., Mullis, I.V.S., Gonzalez, E.J., \& Chrostowski, S.J. (2004). Findings from IEA's Trends in International Mathematics and Science Study at the fourth and eighth Grades. Chestnut Hill, MA: TIMSS \& PIRLS International Study Center, Boston College.

Mellon, Constance (1986). Library anxiety: A grounded theory and its development. College \& Research Libraries, 47(2): 160-165.

National Science Board [NSB], (2007). A National Action Plan for Addressing the Critical Needs of the U.S. Science, Technology, Engineering and Mathematics Education System. Arlington, VA: National Science Foundation. Retrieved from http://www.nsf.gov/nsb/documents/2007/stem_action.pdf

Organization for Economic Cooperation and Development [OECD] (2006). Assessing scientific, reading and mathematical literacy: A framework for PISA 2006. Retrieved April 24, 2009 from http://www.oecd.org/dataoecd/63/35/37464175.pdf

Organization for Economic Cooperation and Development [OECD] (2007). PISA 2006: Science competencies for tomorrow's world. Retrieved April 30, 2009 from http://www.oecd.org/dataoecd/63/35/37464175.pdf 
Schultz-Jones, Barbara. (2009). School library media specialists connect: Collaboration in the school social network. Knowledge Quest, 37(4), 20-25.

Schultz-Jones, Barbara. \& Ledbetter, Cynthia. (2009, January). Collaboration opportunities in the school social network: Science teachers and school library media specialists report. Paper presented at the 7th Annual Hawaii International Conference on Education, January 4 - 7, 2009, Honolulu, HI.

Small, Ruth. (2002). Collaboration: Where does it begin? Teacher Librarian, 29(5) Retrieved May 18, 2009 from http://www.teacherlibrarian.com/tlmag/v_29/v_29_5_feature.html

Todd, Ross. (2008). The evidence-based manifesto. School Library Journal, 54(4), 38-43.

Wolcott, L.L., Lawless, K.A., \& Hobbs, D. (1999). Assessing pre-service teachers' beliefs about the role of the library media specialist. ERIC Clearinghouse on Information \& Technology (ED437065).

\section{Biographical Notes}

Barbara Schultz-Jones has been an Assistant Professor in the Department of Library and Information Sciences at the University of North Texas since 2007 and her research area is school librarian collaboration networks in the school learning environment.

Cynthia Ledbetter has been a Professor in the Department of Science/Mathematics Education at The University of Texas at Dallas since 1987 and her research interests are science learning environments and the role of the school library in the learning process.

Richard Jones has been an Associate Professor in the Chemistry and Physics Department at Texas Woman's University since 1995 and his research interests are undergraduate science education and information literacy.

\section{Statement of Originality}

This statement certifies that the paper above is based upon original research undertaken by the author and that the paper was conceived and written by the author(s) alone and has not been published elsewhere. All information and ideas from others is referenced. 